\title{
Low-Power Ion Thruster Development Status
}

\author{
Michael J. Patterson
}

Lewis Research Center, Cleveland, Ohio 
Since its founding, NASA has been dedicated to the advancement of aeronautics and space science. The NASA Scientific and Technical Information (STI) Program Office plays a key part in helping NASA maintain this important role.

The NASA STI Program Office is operated by Langley Research Center, the Lead Center for NASA's scientific and technical information. The NASA STI Program Office provides access to the NASA STI Database, the largest collection of aeronautical and space science STI in the world. The Program Office is also NASA's institutional mechanism for disseminating the results of its research and development activities. These results are published by NASA in the NASA STI Report Series, which includes the following report types:

- TECHNICAL PUBLICATION. Reports of completed research or a major significant phase of research that present the results of NASA programs and include extensive data or theoretical analysis. Includes compilations of significant scientific and technical data and information deemed to be of continuing reference value. NASA's counterpart of peerreviewed formal professional papers but has less stringent limitations on manuscript length and extent of graphic presentations.

- TECHNICAL MEMORANDUM. Scientific and technical findings that are preliminary or of specialized interest, e.g., quick release reports, working papers, and bibliographies that contain minimal annotation. Does not contain extensive analysis.

- CONTRACTOR REPORT. Scientific and technical findings by NASA-sponsored contractors and grantees.
- CONFERENCE PUBLICATION. Collected papers from scientific and technical conferences, symposia, seminars, or other meetings sponsored or cosponsored by NASA.

- SPECIAL PUBLICATION. Scientific, technical, or historical information from NASA programs, projects, and missions, often concerned with subjects having substantial public interest.

- TECHNICAL TRANSLATION. Englishlanguage translations of foreign scientific and technical material pertinent to NASA's mission.

Specialized services that complement the STI Program Office's diverse offerings include creating custom thesauri, building customized data bases, organizing and publishing research results ... even providing videos.

For more information about the NASA STI Program Office, see the following:

- Access the NASA STI Program Home Page at http://www.sti.nasa.gov

- E-mail your question via the Internet to help@sti.nasa.gov

- Fax your question to the NASA Access Help Desk at (301) 621-0134

- Telephone the NASA Access Help Desk at (301) 621-0390

- Write to:

NASA Access Help Desk

NASA Center for AeroSpace Information 7121 Standard Drive

Hanover, MD 21076 
NASA/TM-1999-208822

AIAA 98-3347

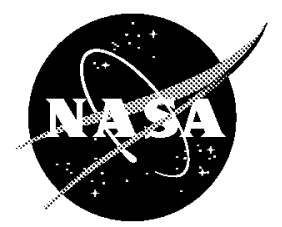

\section{Low-Power Ion Thruster Development Status}

Michael J. Patterson

Lewis Research Center, Cleveland, Ohio

Prepared for the

34th Joint Propulsion Conference and Exhibit cosponsored by AIAA, ASME, SAE, and ASEE

Cleveland, Ohio, July 13-15, 1998

National Aeronautics and

Space Administration

Lewis Research Center 


\section{Acknowledgments}

The author would like to gratefully acknowledge the mechanical support in thruster hardware fabrication provided by Mr. Mike Pastel, Mr. Robert Roman, and Mr. Walt Wozniak.

Available from

NASA Center for Aerospace Information 7121 Standard Drive

Hanover, MD 21076

Price Code: A03
National Technical Information Service 5285 Port Royal Road Springfield, VA 22100 Price Code: A03 


\title{
Low-Power Ion Thruster Development Status
}

\author{
Michael J. Patterson ${ }^{1}$ \\ National Aeronautics and Space Administration \\ Lewis Research Center \\ Cleveland, Ohio
}

An effort is on-going to examine scaling relationships and design criteria for ion propulsion systems, and to address the need for a light weight, low power, high specific impulse propulsion option for small spacecraft. An element of this activity is the development of a low-power (sub- $0.5 \mathrm{~kW}$ ) ion thruster. This development effort has led to the fabrication and preliminary performance assessment of an $8 \mathrm{~cm}$ prototype xenon ion thruster operating over an input power envelope of 0.1-0.3 kW. Efficiencies for the thruster vary from 0.31 at 1750 seconds specific impulse at $0.1 \mathrm{~kW}$, to about 0.48 at 2700 seconds specific impulse and $0.3 \mathrm{~kW}$ input power. Discharge losses for the thruster over this power range varied from about 320-380 W/A down to about 220-250 W/A. Ion optics performance compare favorably to that obtained with $30 \mathrm{~cm}$ ion optics, when scaled for the difference in beam area. The neutralizer, fabricated using $3 \mathrm{~mm}$ hollow cathode technology, operated at keeper currents of about 0.2-0.3 A, at a xenon flow rate of about $0.06 \mathrm{mg} / \mathrm{s}$, over the $0.1-0.3 \mathrm{~kW}$ thruster input power envelope.

\section{Introduction}

A general need for light weight, low power (sub- $0.5 \mathrm{~kW}$ ) ion propulsion technology has been identified for small spacecraft exploration missions, ${ }^{1-3}$ with thruster lifetime requirements as high as 14,000 hours (at $0.2 \mathrm{~kW}$ ) and a total-impulse requirement of $3.0 \times 10^{5} \mathrm{~N}-\mathrm{s} .^{1}$ A xenon ion propulsion system with a throttleable $0.5-2.3 \mathrm{~kW} 30 \mathrm{~cm}$ diameter ion thruster is currently under development by the NASA Solar Electric Propulsion Technology Application Readiness (NSTAR) Program for use on planetary science spacecraft. ${ }^{4}$ This system is rapidly approaching flight status and is scheduled to be used for primary propulsion on the New Millennium Deep Space-1 mission.

The NSTAR system, however, is not an optimal high specific impulse option for very small spacecraft, because of the inherent limited power, volume, and thermal control capacity available on-board. Previous development efforts have brought low-power ion thrusters to a high state of technology readiness, including a flight-type mercury ion thruster, ${ }^{5,6}$ as well as the Hughes $13 \mathrm{~cm}$ xenon ion thruster. ${ }^{7}$ However mercury propellant is no longer a viable option, and the Hughes thruster may not be optimal for small spacecraft from a mass standpoint.

To address these requirements, an effort continues to examine scaling relationships/design criterion for low power ion systems. This development effort to date has led to the fabrication of a small $(8 \mathrm{~cm}$ beam diameter) $0.25-\mathrm{kW}$ class laboratory model ion thruster, and the fabrication and testing of low-flow rate hollow cathode technology. Development objectives for the $8 \mathrm{~cm}$ thruster include a thruster lifetime of $\geq 8000$ hours at full power $(0.3 \mathrm{~kW})$, corresponding to a total impulse capability at full power of approximately $3.3 \times 10^{5} \mathrm{~N}-\mathrm{s}$ or equivalently, $11 \mathrm{~kg}$ of xenon. ${ }^{8}$ Additionally, a parallel effort to develop a breadboard power processor for operation in the $0.1-0.3 \mathrm{~kW}$ power range is on-going. ${ }^{9,10}$

This paper discusses the preliminary performance data obtained for an $8 \mathrm{~cm}$ laboratory model (prototype) xenon ion thruster operating over an input power envelope of approximately $0.1 \mathrm{~kW}$ to $0.3 \mathrm{~kW}$. The performance characteristics of thruster components, including discharge chamber, ion optics, and discharge and neutralizer cathodes, are also documented.

\section{Prototype Thruster Design}

This section briefly describes the mechanical design of the prototype $8 \mathrm{~cm}$ ion thruster. The thruster, less plasma screen, is shown in Figure 1. The neutralizer assembly, an open-keeper configuration, is shown in Figure 2.

\section{Ion Optics}

For these preliminary performance characterizations, the $8 \mathrm{~cm}$ thruster used a 2-grid molybdenum electrode configuration assembled from flight spare hardware originally developed for the Ion Auxiliary Propulsion System (IAPS) Mercury $8 \mathrm{~cm}$ thruster. ${ }^{5,11}$ The optics have an electrode geometry (hole diameter and pattern,

${ }^{1}$ Aerospace Engineer, Member AIAA 
electrode thickness, and interelectrode gap) identical to that used in the $30 \mathrm{~cm}$ NSTAR thruster ion optics. These include a screen electrode thickness of $0.38 \mathrm{~mm}$ with hole diameters of $1.91 \mathrm{~mm}$, and accelerator electrode thickness of $0.51 \mathrm{~mm}$ with hole diameters of $1.14 \mathrm{~mm}$.

Notable exceptions to the NSTAR configuration include the beam diameter, the electrode mounting system, and the direction of the electrode dish. The mounting system used for the thruster optics differs from that implemented on the NSTAR thruster in both material and configuration. The electrodes do not incorporate stiffening or mounting rings, but are mechanically supported in four places around the electrode periphery by insulated posts brazed to the electrodes (see for example Fig.12 of reference 11). These posts then directly interface to the thruster discharge chamber. The inner electrode of the ion optics is electrically-tied to cathode potential. Additionally, the ion optics for the $8 \mathrm{~cm}$ have a concave, or "dished-in," direction of curvature, opposite that employed in the NSTAR thruster. This feature reduces the near-field beam spread, potentially allowing for easier thruster integration on small spacecraft.

\section{Discharge Chamber}

The thruster performance and lifetime objectives necessitate that the discharge chamber operate at high values of electrical and propellant efficiency. As such, emphasis has been placed on modeling and optimization of the discharge chamber magnetic circuit design to ensure that acceptable discharge losses and voltages are achieved. Much of this work, performed without beam extraction, is documented in a companion paper. ${ }^{12}$

A multiple-ring, ring-cusp magnetic configuration composed of permanent magnets was selected for the thruster discharge, with the discharge chamber surfaces constructed of a non-ferromagnetic material. The advantage of using a high-magnetic flux rare-Earth permanent magnet configuration is that it efficiently contains the primary electrons, and permits high efficiency discharge operation at low values of discharge voltage.

The prototype thruster discharge chamber is shown on its test stand in Figure 1. The design uses a conic discharge chamber, which transitions into a cylindrical region upstream of the ion optics. This partial-conic design is inherently more rigid and occupies less volume than conventional cylindrically-shaped thrusters which use large, flat circular rear walls, while still exhibiting good discharge characteristics and promoting a uniform plasma distribution across the exit plane. All discharge chamber surfaces are at anode-potential.

The appropriate discharge chamber length for the thruster was established from neutral loss rate considerations, and the thruster performance targets. ${ }^{8}$ A reverse-feed main plenum is also used in the discharge chamber to increase the propellant efficiencies at throttled power levels.

For performance characterizations of the thruster, lowpressure high-voltage propellant isolators, identical to those implemented on the NSTAR $30 \mathrm{~cm}$ thruster, were used on the discharge cathode and main plenum propellant lines. This isolator design, with cylindrical geometry of $3.9 \mathrm{~cm}$ diameter and $3.6 \mathrm{~cm}$ length, has greater than 400 volts margin over the range of propellant line pressures and beam voltages corresponding to all thruster operating conditions. An alternative propellant isolator design, one substantially more compact in geometry $(0.64 \mathrm{~cm}$ dia. by $2.2 \mathrm{~cm}$ length), is under development for this small thruster but was unavailable at the time of these tests.

\section{Discharge and Neutralizer Cathodes}

The cathodes used in the thruster discharge and neutralizer are constructed from $3 \mathrm{~mm}$ diameter tube/electron emitter technology. They consist of a hollow cathode sub-assembly composed of a high temperature refractory alloy tube and an electron emitting insert impregnated with a low-work function compound. Both assemblies also use a swaged heater used for cathode activation and ignition. The cathode tip orifice diameters for the discharge and neutralizer cathodes were sized to ensure stable long-life operation over the range of anticipated emission currents. The aspect-ratio of the cathode orifice region was adjusted to yield a high ratio of emission current-to-flow rate.

The discharge cathode emission current requirements were estimated (pre-test) to be in the range of about $1.0 \mathrm{~A}$ to $2.0 \mathrm{~A}$ over the $0.1 \mathrm{~kW}$ to $0.3 \mathrm{~kW}$ thruster power envelope. In these series of tests, no discharge cathode keeper or starting electrode were used to facilitate ignition or protect the cathode from discharge ion erosion (as is employed in the NSTAR thruster). Ignition and steadystate operation of the discharge was achieved by directcoupling to the anode. 
The prototype neutralizer assembly employs an openkeeper geometry hollow cathode, as identified in Figure 2. A modest level of design optimization of the neutralizer was conducted (operating in a simple diode, and triode, configuration) prior to integration of the assembly with the thruster. This activity primarily focussed on examining the effect of keeper electrode configuration and cathode-keeper gap on reducing keeper input power, propellant flow rate, and beam coupling voltage.

\section{Apparatus and Procedure}

The following section briefly discusses the test support equipment and procedures used to conduct the performance assessment of the ion thruster.

\section{Power Supplies}

Operation of the prototype thruster with beam extraction was conducted using a power console originally developed for the NASA $30 \mathrm{~cm}$ thruster. ${ }^{13}$ A breadboard power processor for the small thruster was also used for some of the performance tests, and these data are discussed in a companion paper. ${ }^{10}$ The thruster uses 4 power supplies for steady-state operation, with 2 additional power supplies for start-up of the discharge and neutralizer cathodes. Beam power supply voltages ranged from about $800-1250 \mathrm{~V}$, while the accelerator power supply voltage was operated between $-200 \mathrm{~V}$ and $-300 \mathrm{~V}$.

\section{Propellant Management}

An inert gas feed system was designed and constructed for performance assessments of the $8 \mathrm{~cm}$ thruster. The feed system minimizes contaminants in the gas supply by using high purity xenon and by using construction techniques which limit the introduction of contaminants into the gas stream. The feed system also has an in-situ propellant flow rate calibration capability, achieved by a volumetric method, which can verify the accuracy of the flow rate readings, while the thruster is operating, to within $2 \%$ of the reading. The feed system also is capable of controlling the propellant flow rates to within $0.05 \mathrm{sccm}$ ( $1 \%$ of full-scale) to each of the three propellant lines into the thruster (discharge and neutralizer cathodes, and main plenum).

\section{Test Facility}

The test facility (Vacuum Facility \#11 at NASA LeRC) consists of an aluminum vacuum chamber of approximately $2.3 \mathrm{~m}$ in diameter and $4.6 \mathrm{~m}$ in length. The pumping train includes a two-stage blower system backed up by a roughing pump. The chamber is equipped with four $0.9 \mathrm{~m}$ diameter helium refrigerator cryopumps. At the flow rate corresponding to the full-power condition, the background pressure is $\leq 3.9 \times 10^{-4} \mathrm{~Pa}\left(2.9 \times 10^{-6}\right.$ torr $)$.

The test facility includes a test port of $0.9 \mathrm{~m}$ diameter consisting of a $1.1 \mathrm{~m}$ long spool piece and an isolation valve. The thruster and propellant feed system are mounted onto a test cart, with a flange that mates to the $0.9 \mathrm{~m}$ diameter spool piece. The test port allows the thruster to be installed and removed from the vacuum chamber rapidly, without bringing the entire chamber to atmosphere.

\section{Procedure}

The thruster was operated under manual control for all performance testing. Data were recorded from calibrated digital metering. All thruster performance data were corrected for thrust losses associated with beam divergence and doubly-charged ions. Total thruster efficiency and specific impulse calculations included losses associated with accelerator drain and neutralizer power, and neutralizer cathode propellant flow rate. All propellant efficiencies included a correction to the mass flow rate for propellant ingested from the facility. A detailed discussion of the thruster performance calculations can be found in references 14 , and 15 .

\section{Thruster Performance}

Preliminary performance data for the thruster were obtained over a $0.1 \mathrm{~kW}-0.3 \mathrm{~kW}$ power envelope. The thruster performance characteristics presented in this section include discharge chamber, ion optics, cathode, and overall thruster efficiency.

\section{Discharge Chamber}

Figure 3 shows the measured discharge chamber losses, in watts per beam ampere of ion current, as a function of thruster input power, over the $0.1 \mathrm{~kW}-0.3 \mathrm{~kW}$ power range investigated. The corresponding propellant efficiencies for these conditions varied from about 0.68 to 0.78 , corrected for both ingested flow and doublycharged ions. All data were obtained at low values of discharge voltage which should provide long life operation (25-32 V, with most data at $\leq 29$ volts). Maximum magnet temperatures, at the discharge power level corresponding to $0.3 \mathrm{~kW}$ (as measured without beam extraction), were measured to be about 230 degrees C; well below the temperature expected to yield any irreversible losses. 
As indicated in Figure 3, the discharge losses vary from about 320-380 W/A at 100-110 W, down to about 220$250 \mathrm{~W} / \mathrm{A}$ at $270-310 \mathrm{~W}$ input power. Scatter in the data reflect some variation in the propellant efficiency and discharge voltage at each thruster input power. The data indicate a general decrease in discharge losses with input power. This would be expected with increasing power (beam current) due to an increase in discharge plasma density and enhanced electron ionization efficiency.

Also plotted on Figure 3 are the previously-published performance targets for this small thruster discharge chamber, which range from about $330 \mathrm{~W} / \mathrm{A}$ at $100 \mathrm{~W}$ to $266 \mathrm{~W} / \mathrm{A}$ at $300 \mathrm{~W} .{ }^{1}$ As indicated, the discharge chamber performance documented here meets or exceeds these levels at all but the lowest input power, albeit at somewhat lower propellant efficiency.

Figure 4 shows the discharge losses, in watts per beam ampere of ion current, versus discharge propellant efficiency for several thruster input power levels. As indicated, the baseline discharges losses decrease with increasing input power, with the knee of the characteristic at about $0.73-0.75$ propellant efficiency.

\section{Ion Optics}

As indicated previously, a 2-grid ion optics system originally developed for the IAPS thruster, was used. The electrodes were pristine, and were set with a cold interelectrode gap of $0.66 \mathrm{~mm}$, with screen grid and accelerator grid open-area-fractions of 0.67 and 0.24 , respectively. For these tests, no procedures were employed to optimize ion optics configuration or performance beyond an initial alignment and cold gap setting. Over the course of the testing, few high voltage breakdowns were experienced; typically less than 0.2 /hour.

Figure 5 shows accelerator drain current as a function of total acceleration voltage, for a range of beam current values corresponding to approximately a $0.1-0.3 \mathrm{~kW}$ power envelope. From these characteristics, a relationship between extracted ion beam current and total accelerating voltage was obtained. The minimum total accelerating voltage was defined to be at the knee of the characteristic curves of Fig. 5, corresponding to a slope of about $-30 \mu \mathrm{A} / \mathrm{V}$. The perveance-limited beam current measured for these $8 \mathrm{~cm}$ optics can then be expressed as:

$$
J_{b}=3.9 * 10^{-6} * V_{t}^{1.5}, \quad A,
$$

where $J_{b}$ is the beam current in amperes, and $V_{t}$ is the total accelerating voltage. From equation 1 , the perveance of the optics yields about a 200 volt margin at the target 0.1 $\mathrm{kW}$ condition, and about 125 volt margin at $0.3 \mathrm{~kW}$.

Normalizing the perveance to beam area, the performance of these optics compare favorably (to within $2 \%$ ) to that obtained and reported for $30 \mathrm{~cm}(28.2 \mathrm{~cm}$ effective beam diameter) optics of comparable electrode geometry and cold interelectrode gap. ${ }^{14}$ This is somewhat surprising in that the interelectrode gap for the concave-shaped $8 \mathrm{~cm}$ optics would be expected to increase from their initial cold value, and result in lower perveance, while the convex-shaped $30 \mathrm{~cm}$ optics gap should decrease, yielding higher perveance.

Figure 6 plots the magnitude of the minimum accelerator grid voltage, required to inhibit electron backstreaming, as a function of thruster input power. As indicated, the voltage increases in magnitude from about 75 volts at 0.1 $\mathrm{kW}$, to about 115 volts at $0.3 \mathrm{~kW}$. These values yield an accelerator grid voltage margin of about 125 volts at low power, and 185 volts at high power, as compared to the nominal operating values of 200 and 300 volts. $^{8}$

The ratio of the accelerator drain current-to-beam current, $J_{a} / J_{b}$, is about $0.5 \%$ for all operating conditions. At the associated discharge propellant efficiencies $(\leq 0.78)$, the baseline accelerator current is likely primarily chargeexchange ion current, with little direct-impingement.

\section{Discharge and Neutralizer Cathodes}

After an initial pre-heat of approximately 2.5 minutes, discharge and neutralizer cathode ignitions were typically achieved using an open-circuit voltage of 40 volts, at xenon flow rates corresponding to full power operation (approximately $0.22 \mathrm{mg} / \mathrm{s}$ for the discharge cathode, and $0.06 \mathrm{mg} / \mathrm{s}$ for the neutralizer cathode). The discharge cathode emission current requirement varied from about 1.0 to $1.6 \mathrm{~A}$ over the $0.1-0.3 \mathrm{~kW}$ power range. The fraction of the total discharge propellant flow rate through the cathode varied from about $50 \%$ at $0.1 \mathrm{~kW}$ to as high as $100 \%$ at full power.

For these preliminary tests, the neutralizer cathode was designed with an open-keeper configuration (see Fig. 2). Figure 7 shows the typical values of keeper current and power, over the range of thruster input power levels. As indicated, the keeper current in general decreased with thruster input power, and varied from about $0.28 \mathrm{~A}$ down to $0.20 \mathrm{~A}$, while the total emission current varied from about $0.33 \mathrm{~A}$ to $0.39 \mathrm{~A}$. The corresponding keeper power varied from about $9.9 \mathrm{~W}$ at $0.1 \mathrm{~kW}$ thruster input power, down to a minimum of about $3.6 \mathrm{~W}$ at $0.3 \mathrm{~kW}$ thruster 
input power. At these conditions, the neutralizer propellant flow rate varied from $0.05-0.06 \mathrm{mg} / \mathrm{s}(0.54-0.61$ sccm). For all operating conditions, the neutralizer coupling voltage (potential difference between neutralizer-common and facility ground) was between 15.9-17.9 volts in magnitude.

While the neutralizer cathode performance is representative of state-of-the-art, an additional factor of 2 reduction in keeper current will be required to achieve the published performance goals for the neutralizer. ${ }^{1}$ This reduction in keeper power is likely achievable via improved thermal design, and via modifications to the cathode and keeper orifice plates to reduce ion recombination losses.

\section{Overall Thruster Efficiency}

Characterization of overall thruster efficiency was accomplished by establishing the discharge chamber operating conditions at a given beam current, adjusting the neutralizer to an optimal condition, and adjusting the total accelerating voltage. The total accelerating voltage was established with appropriate voltage margin from the perveance-limited current, and with a net-to-total accelerating voltage in the range of $0.75-0.85$ while maintaining an electron backstreaming margin of greater than 100 volts.

Figures 8 and 9 show the overall thruster efficiency versus specific impulse and thruster input power, respectively. As indicated in Figure 8, the efficiency varied from approximately 0.31 at 1750 seconds, to about 0.48 at 2700 seconds. From Figure 9, the thruster efficiency was 0.31 at $0.1 \mathrm{~kW}$, approximately 0.43 at $0.2 \mathrm{~kW}$, and about $0.47-0.48$ at $0.3 \mathrm{~kW}$. These values are somewhat below the performance targets established for the thruster, which are approximately 0.38 at $0.1 \mathrm{~kW}, 0.48$ at $0.2 \mathrm{~kW}$, and 0.54 at $0.3 \mathrm{~kW} .^{1}$

The difference in demonstrated versus target values can be accounted for by a lower-than-anticipated discharge chamber propellant efficiency, and high neutralizer input power. Additional refinements in neutralizer design alone, however, are expected to increase thruster efficiencies by at least 3 percentage points over the power range.

Table I lists the thruster performance parameters obtained at $0.1 \mathrm{~kW}, 0.2 \mathrm{~kW}$, and $0.3 \mathrm{~kW}$. While below the ultimate performance targets, the thruster efficiencies documented in Figures 8 and 9, and Table I, compare favorably to other thrusters. For example, the $8 \mathrm{~cm}$ thruster efficiencies at $0.2 \mathrm{~kW}$ and $0.3 \mathrm{~kW}$ are a factor of
2 higher than those demonstrated with the NSTAR thruster. The $8 \mathrm{~cm}$ thruster performance at $0.30 \mathrm{~kW}$ of about 0.48 efficiency and 2650 seconds specific impulse compares well with that of the Hughes $13 \mathrm{~cm}$ thruster performance of 0.51 efficiency and 2590 seconds at about $50 \%$ higher input power $(0.44 \mathrm{~kW}){ }^{7}$

\section{Development Activities}

Refinements in thruster mechanical design, and additional performance documentation, are warranted (using laboratory-class hardware) prior to fabrication of an engineering model $8 \mathrm{~cm}$ thruster. These refinements will focus on improving overall thruster efficiency by decreasing the discharge neutral loss rate (while maintaining or decreasing the electrical losses), as well as by further reductions in neutralizer power and propellant consumption. Other thruster activities will include documenting the power-throttling envelope of the thruster, including determining thermal limits, and quantifying the near-field beam, including charge-state.

\section{Summary}

As part of an activity to address the need for a light weight, low power, high specific impulse propulsion option for small spacecraft, a sub-0.5 kW, $8 \mathrm{~cm}$ beam diameter, prototype ring-cusp ion thruster, and associated test support equipment, were fabricated. A preliminary performance assessment of the thruster on xenon propellant was completed over an input power envelope of 0.1 $0.3 \mathrm{~kW}$, and the operation of various components were documented.

Discharge chamber performance values for the ring-cusp thruster were 0.68 to 0.78 propellant efficiency, and discharge losses from about $320-380 \mathrm{~W} / \mathrm{A}$ at $0.1 \mathrm{~kW}$, down to about $220-250 \mathrm{~W} / \mathrm{A}$ at $0.3 \mathrm{~kW}$ thruster input power. Discharge voltages ranged from $25-32 \mathrm{~V}$, with most data at $\leq 29$ volts. The documented discharge chamber performance for the thruster met or exceeded the previously-published targets of about $330 \mathrm{~W} / \mathrm{A}$ at $0.1 \mathrm{~kW}$ to $266 \mathrm{~W} / \mathrm{A}$ at $0.3 \mathrm{~kW}$.

The perveance-limited beam current measured for thruster ion optics yields about a 200 volt margin at the target 0.1 $\mathrm{kW}$ condition, and about 125 volt margin at $0.3 \mathrm{~kW}$. The perveance-per-unit area for the optics are nearly identical to that previously reported for $30 \mathrm{~cm}$ optics of comparable electrode geometry and cold interelectrode gap. Measurements of electron-backstreaming indicate a large ( $\geq 125$ volt) accelerator grid voltage margin at the target operating conditions, over the full power range. 
Both the discharge and neutralizer cathodes were fabricated from $3 \mathrm{~mm}$ hollow cathode technology. Typical discharge cathode emission current requirements varied from about 1.0 to $1.6 \mathrm{~A}$ over the $0.1-0.3 \mathrm{~kW}$ power range. The open-keeper neutralizer operated at keeper currents of about 0.2-0.3 A, keeper input power levels of about $4-10 \mathrm{~W}$, at a xenon flow rate of about $0.06 \mathrm{mg} / \mathrm{s}$ over the same power range.

Overall thruster efficiencies varied from about 0.31 at 1750 seconds specific impulse and $0.1 \mathrm{~kW}$, to about 0.48 at 2700 seconds specific impulse and $0.3 \mathrm{~kW}$ input power, and these values compare favorably to other thrusters operating in this power range. Further improvements in discharge chamber and neutralizer design to increase overall thruster efficiency are anticipated.

\section{References}

${ }^{1}$ Patterson, M.J. and Oleson, S.R., "Low-Power Ion Propulsion for Small Spacecraft," AIAA Paper No. 973060, July 1997. (Also NASA TM-113111).

${ }^{2}$ Brophy, J.R, "Advanced Ion Propulsion Technology for Solar System Exploration," AIAA Paper No. 97-2782, July 1997.

3"Representative Mission Requirements for Micropropulsion Systems," Sercel, J., presentation at the JPL Micropropulsion Workshop, April 1997.

${ }^{4}$ Sovey, J.S., et al., “Development of an Ion Thruster and Power Processor for New Millennium's Deep Space 1 Mission," AIAA Paper No. 97-2778, July 1997.

${ }^{5}$ Power, J.L., "Planned Flight Test of a Mercury Ion Auxiliary Propulsion System - Objectives, System Descriptions, and Mission Operations," NASA TM-78859, April 1978.

${ }^{6}$ Collett, C. and Power, J.L, "Qualification Test Results of IAPS $8 \mathrm{~cm}$ Ion Thrusters," AIAA Paper No. 82-1954.

${ }^{7}$ Beattie, J.R., Williams, J.D., and Robson, R.R., "Flight Qualification of an 18-mN Xenon Ion Thruster," IEPC Paper No. 93-106.

${ }^{8}$ Patterson, M.J., Grisnik, S.P., and Soulas, G.C., "Scaling of Ion Thrusters to Low Power," IEPC Paper No. 97-098, August 1997.

${ }^{9}$ Pinero, L.R., Patterson, M.J., and Bowers, G.E., "Power Processor for a 200 W-Class Xenon Ion Thruster," IEPC Paper No. 97-099, August 1997.

${ }^{10}$ Pinero, L.R., Patterson, M.J., and Bowers, G.E., "Integration of a Power Processing Unit for Low Power Ion Thrusters," AIAA Paper No. 98-3652, July 1998.
${ }^{11}$ Dulgeroff, C.R., et al., "IAPS (8-CM) Ion Thruster Cyclic Endurance Test,” IEPC Paper No. 84-37, 1984.

${ }^{12}$ Menart, J. and Patterson, M.J., "Discharge Chamber Characteristics for Small Ion Thrusters Using Two Magnetic Circuit Configurations," AIAA Paper No. 983343, July 1998.

${ }^{13}$ Pinero, L.R., Patterson, M.J., and Satterwhite, V.E., "Power Console Development for NASA's Electric Propulsion Outreach Program," IEPC Paper No. 93-250, September 1993.

${ }^{14}$ Patterson, M.J., "Low-Isp Derated Ion Thruster Operation,” AIAA Paper No. 92-3203, July 1992.

${ }^{15}$ Patterson, M.J., Haag, T.W, and Hovan, S.A., "Performance of the NASA $30 \mathrm{~cm}$ Ion Thruster," IEPC Paper No. 93-108, September 1993. (Also NASA TM106426).

Table I - Preliminary $8 \mathrm{~cm}$ Thruster Performance

\begin{tabular}{|l||c|c|c|}
\hline Parameter & $0.1 \mathrm{~kW}$ & $0.2 \mathrm{~kW}$ & $0.3 \mathrm{~kW}$ \\
\hline Thrust, mN & 3.6 & 7.7 & 10.9 \\
\hline Efficiency & 0.31 & 0.42 & 0.48 \\
\hline Specific Impulse, sec & 1760 & 2260 & 2650 \\
\hline \hline Discharge Voltage, V & 26 & 30 & 30 \\
\hline Discharge Current, A & 1.13 & 1.49 & 1.55 \\
\hline Discharge Flow Rate, mg/s & 0.15 & 0.29 & 0.36 \\
\hline Discharge Losses, W/A & 360 & 290 & 240 \\
\hline $\begin{array}{l}\text { Discharge Chamber } \\
\text { Propellant Eff. }\end{array}$ & 0.73 & 0.74 & 0.73 \\
\hline \hline Beam Power Supply Voltage, V & 800 & 960 & 1250 \\
\hline Beam Current, mA & 80.9 & 156 & 194 \\
\hline Accelerator Voltage, IVI & 200 & 300 & 300 \\
\hline Accelerator Current, mA & 0.41 & 0.78 & 1.02 \\
\hline \hline \begin{tabular}{l||} 
Neutralizer Keeper Voltage, V \\
\hline Neutralizer Keeper Current, A
\end{tabular} & 0.25 & 0.20 & 0.20 \\
\hline Neutralizer Coupling Voltage, IVI & 17 & 17 & 17 \\
\hline Neutralizer Flow Rate, mg/s & 0.06 & 0.06 & 0.06 \\
\hline
\end{tabular}




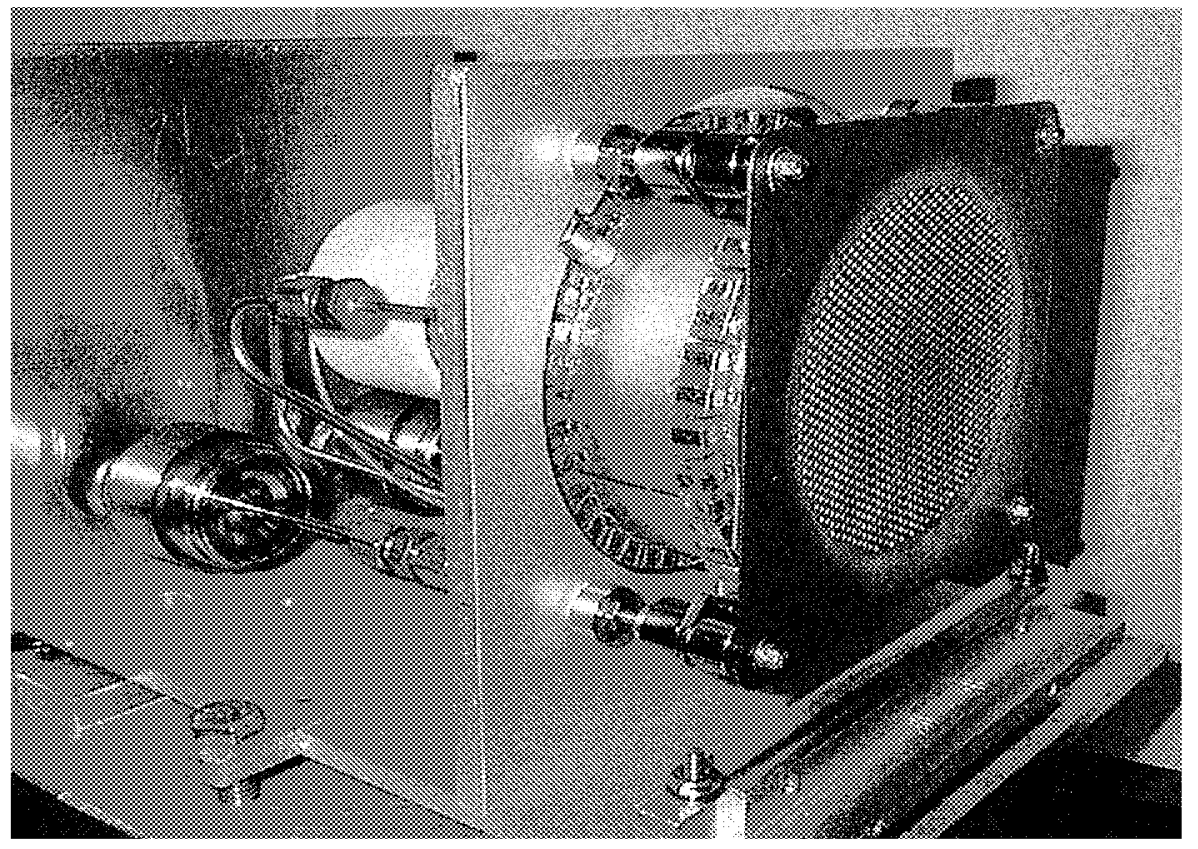

Figure 1. - Prototype $8 \mathrm{~cm}$ ion thruster with plasma screen removed.

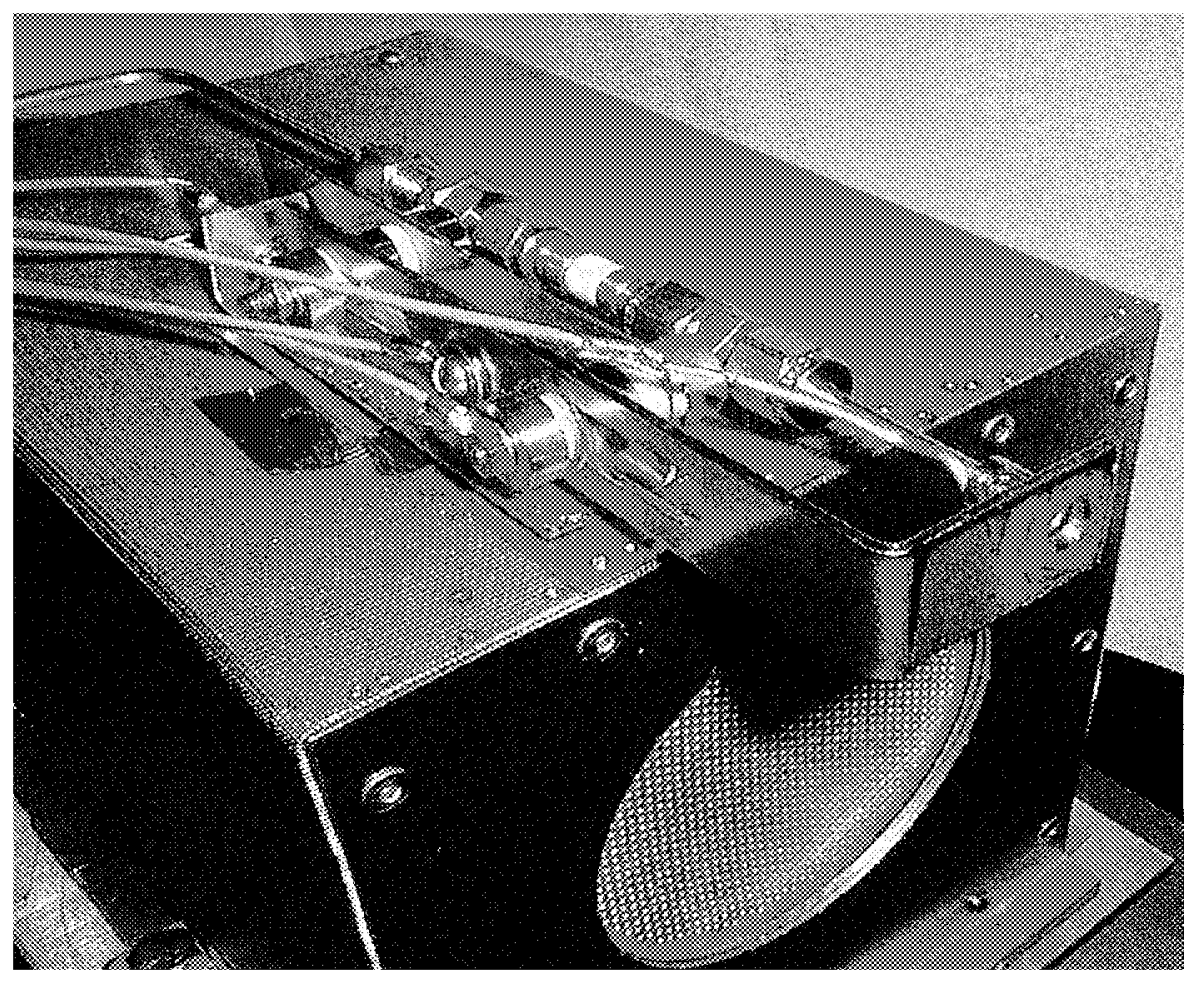

Figure 2. - Neutralizer assembly; open-keeper configuration. 


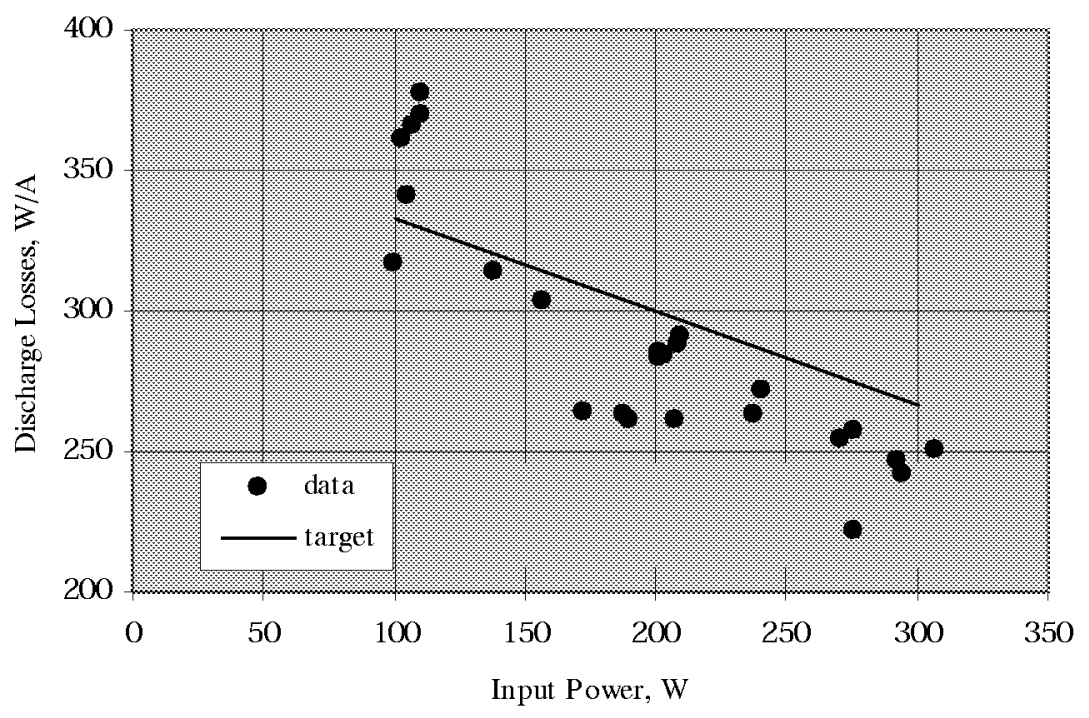

Figure 3. - Discharge chamber losses vers us thruster input power.

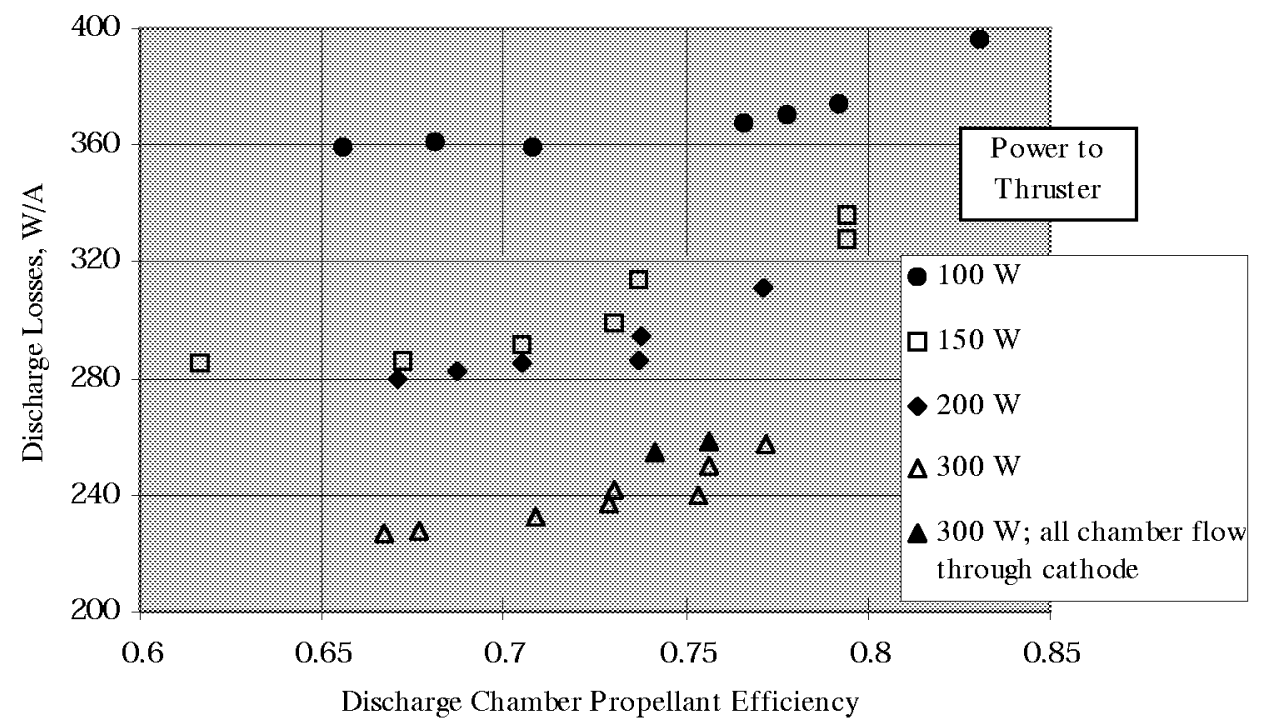

Figure 4. - Discharge chamber losses vers us discharge propellant efficiency. 


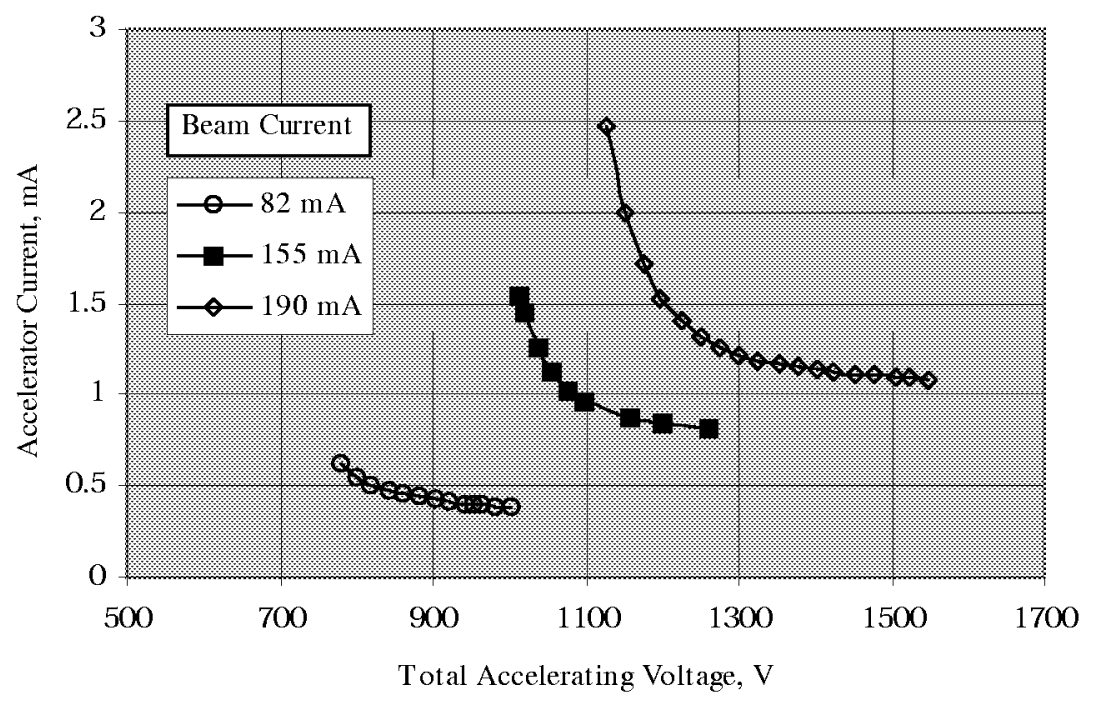

Figure 5. - Accelerator current versus total accelerating voltage.

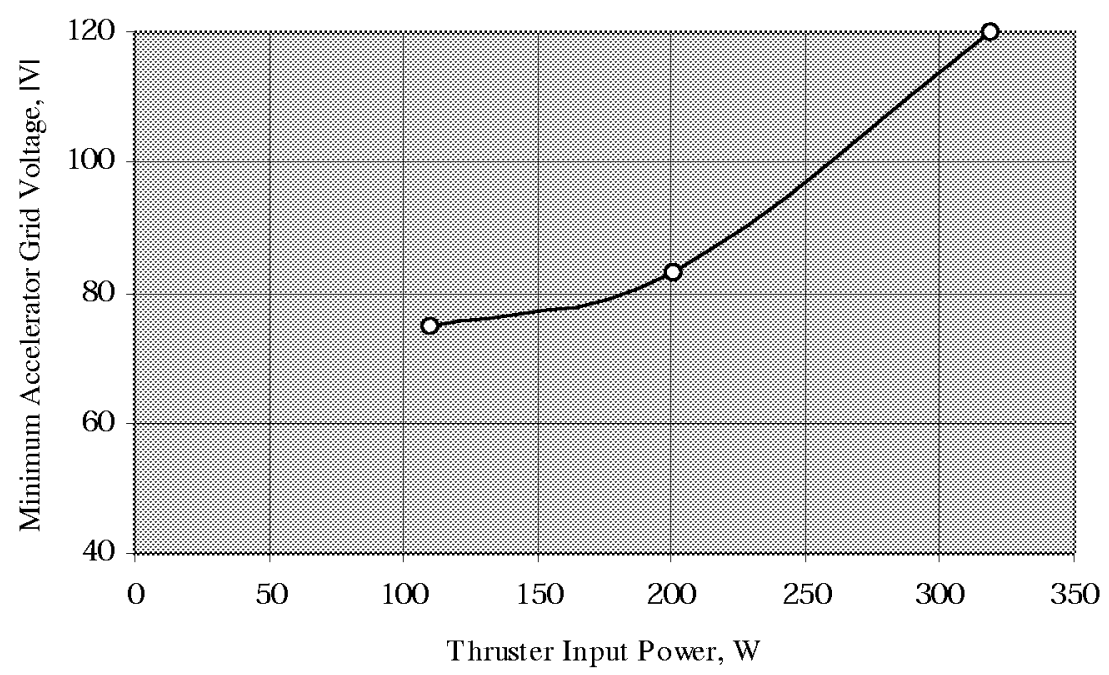

Figure 6. - Minimum accelerator grid voltage to prevent electron backstreaming versus thruster input power. 


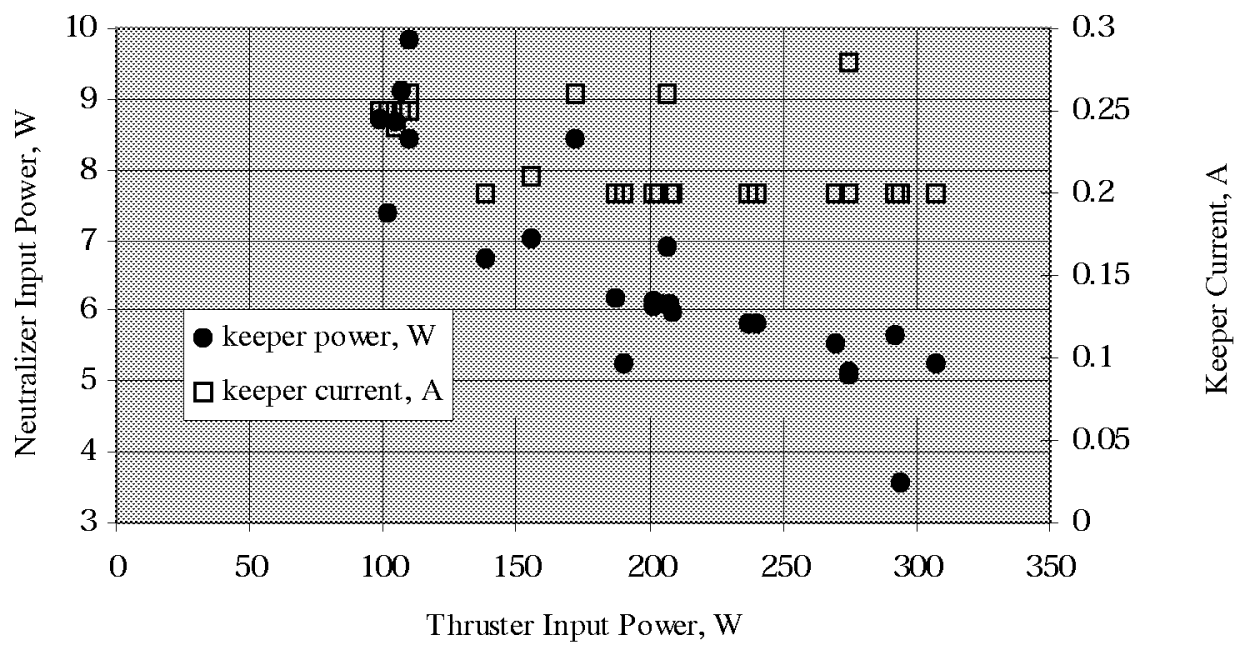

Figure 7. - Neutralizer performance versus thruster input power.

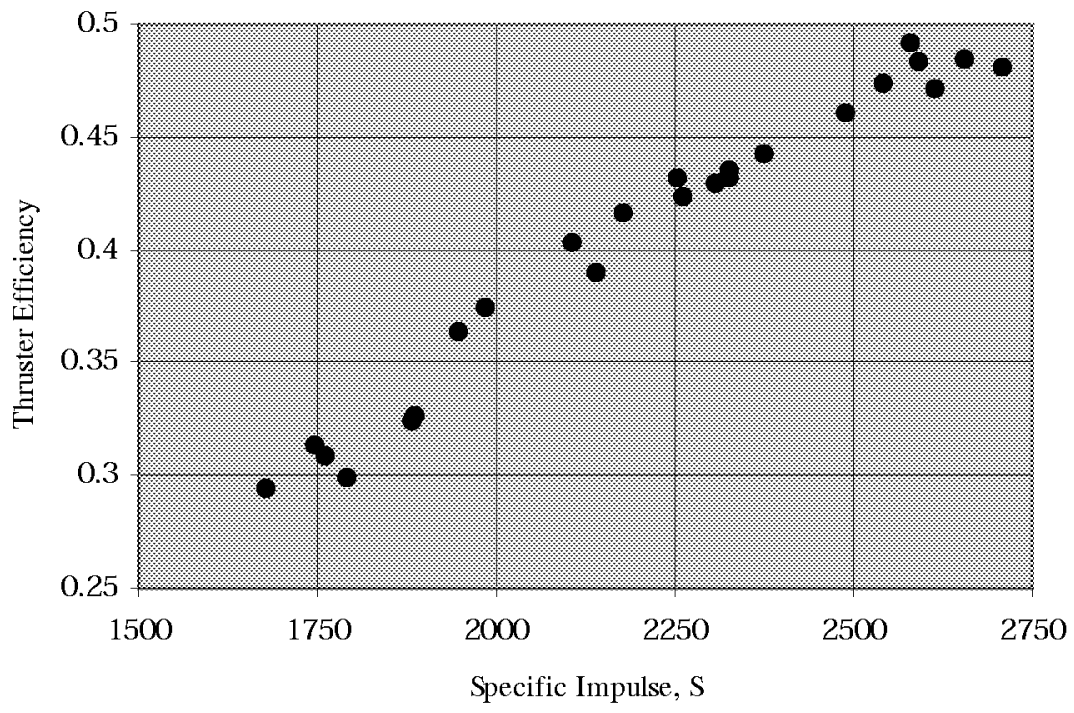

Figure 8. - Thruster efficiency versus specific impulse. 


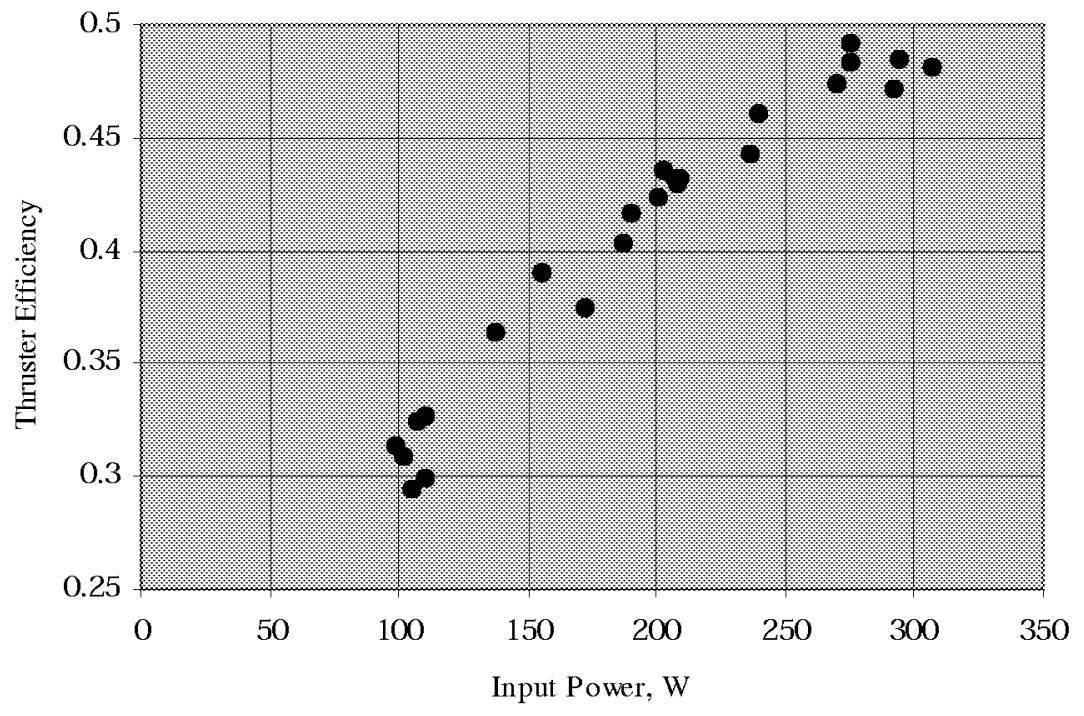

Figure 9. - Thruster efficiency versus thruster input power. 
\begin{tabular}{|l|c|c|}
\hline 1. AGENCY USE ONLY (Leave blank) & $\begin{array}{c}\text { 2. REPORT DATE } \\
\text { January } 1999\end{array}$ & $\begin{array}{r}\text { 3. REPORT TYPE AND DATES COVERED } \\
\text { Technical Memorandum }\end{array}$
\end{tabular}

\section{TITLE AND SUBTITLE}

\section{FUNDING NUMBERS}

Low-Power Ion Thruster Development Status

6. AUTHOR(S)

Michael J. Patterson

\section{PERFORMING ORGANIZATION NAME(S) AND ADDRESS(ES)}

National Aeronautics and Space Administration

Lewis Research Center

Cleveland, Ohio 44135-3191

9. SPONSORING/MONITORING AGENCY NAME(S) AND ADDRESS(ES)

National Aeronautics and Space Administration

Washington, DC 20546-0001
WU-022-00-00-00

8. PERFORMING ORGANIZATION REPORT NUMBER

E-11428

\section{SUPPLEMENTARY NOTES}

Prepared for the 34th Joint Propulsion Conference and Exhibit cosponsored by AIAA, ASME, SAE, and ASEE, Cleveland, Ohio, July 13-15, 1998. Responsible person, Michael J. Patterson, organization code 5430, (216) 977-7481.

Unclassified - Unlimited

Subject Categories: 16 and 20

Distribution: Nonstandard

This publication is available from the NASA Center for AeroSpace Information, (301) 621-0390.

\section{ABSTRACT (Maximum 200 words)}

An effort is on-going to examine scaling relationships and design criteria for ion propulsion systems, and to address the need for a light weight, low power, high specific impulse propulsion option for small spacecraft. An element of this activity is the development of a low-power (sub- $0.5 \mathrm{~kW}$ ) ion thruster. This development effort has led to the fabrication and preliminary performance assessment of an $8 \mathrm{~cm}$ prototype xenon ion thruster operating over an input power envelope of $0.1-0.3 \mathrm{~kW}$. Efficiencies for the thruster vary from 0.31 at 1750 seconds specific impulse at $0.1 \mathrm{~kW}$, to about 0.48 at 2700 seconds specific impulse and $0.3 \mathrm{~kW}$ input power. Discharge losses for the thruster over this power range varied from about 320-380 W/A down to about 220-250 W/A. Ion optics performance compare favorably to that obtained with $30 \mathrm{~cm}$ ion optics, when scaled for the difference in beam area. The neutralizer, fabricated using $3 \mathrm{~mm}$ hollow cathode technology, operated at keeper currents of about $0.2-0.3 \mathrm{~A}$, at a xenon flow rate of about $0.06 \mathrm{mg} / \mathrm{s}$, over the $0.1-0.3 \mathrm{~kW}$ thruster input power envelope.

\section{SUBJECT TERMS}

\begin{tabular}{|c|c|}
\hline & $\begin{array}{c}\text { 15. NUMBER OF PAGES } \\
17 \\
\end{array}$ \\
\hline & 16. PRICE CODE \\
\hline & $\mathrm{A} 03$ \\
\hline $\begin{array}{l}\text { 19. SECURITY CLASSIFICATION } \\
\text { OF ABSTRACT }\end{array}$ & 20. LIMITATION OF ABSTRACT \\
\hline Unclassified & \\
\hline
\end{tabular}

Ion propulsion; Ion thrusters; Electric propulsion; Xenon

\begin{tabular}{|c|c|}
\hline $\begin{array}{c}\text { 17. SECURITY CLASSIFICATION } \\
\text { OF REPORT } \\
\text { Unclassified }\end{array}$ & $\begin{array}{c}\text { 18. SECURITY CLASSIFICATION } \\
\text { OF THIS PAGE } \\
\text { Unclassified }\end{array}$ \\
\hline
\end{tabular}

